\title{
Legitimidad sacro-popular y usos de la religiosidad popular durante la guerra civil en Cáceres y Badajoz
}

Sacred-popular legitimacy and uses of popular religiosity during the civil war in Cáceres and Badajoz

César Rina Simón

Universidad de Extremadura

\section{RESUMEN}

En las últimas décadas, la historiografía sobre la construcción de la legitimidad del alzamiento y del nuevo Estado franquista se ha visto enriquecida por múltiples perspectivas. A los trabajos sobre la represión, la violencia y el miedo, se han sumado interpretaciones sociales, económicas, religiosas y culturales que han complejizado las narrativas del consentimiento y de la hegemonía de la dictadura. En este trabajo pretendemos abordar la cuestión desde la perspectiva de la religiosidad y la cultura popular en el caso extremeño, tomando los conceptos de pueblo, tradición y sagrado desde el diálogo transdisciplinar con la Antropología. Para ello abordaremos las múltiples prácticas, rituales y discursos en el contexto de la guerra civil que resignificaron ritos, creencias y expectativas en constante definición y contestación en las ciudades de Cáceres y Badajoz. Este esfuerzo consciente por apropiarse de lo popular y de lo esencial favoreció la consolidación de la dictadura en los horizontes locales como salvaguarda de lo sagrado y de las tradiciones.

PALABRAS CLAVE: franquismo, religiosidad popular, legitimidad, Extremadura, Semana Santa 


\begin{abstract}
In recent decades, the historiography of the legitimacy of the new Francoist State has advanced from multiple perspectives. The classical interpretations of repression, violence and fear have opened the field of study of society, economy and culture and integrated explanations about consent and the hegemony. In this article we use the perspective of religiosity and popular culture in Extremadura (Spain), and the concepts of people, tradition and sacred from the transdisciplinary dialogue with Anthropology. With this objective, we have investigated the plural practices, rituals and discourses in the context of the Spanish Civil War and the resignification of rites, beliefs and expectations in constant definition in Cáceres and Badajoz. The conscious effort to appropriate the popular and the essential favoured the hegemony of the dictatorship in the local horizons.
\end{abstract}

KEY WORDS: Francoism, Popular Religiosity, Legitimacy, Extremadura, Semana Santa

Este trabajo pretende acercarnos a los procesos de legitimación de la sublevación del nuevo Estado franquista en Badajoz y en Cáceres durante la guerra civil. En ambas ciudades, el control y resignificación de la religiosidad popular y de los rituales considerados tradicionales fueron elementos fundamentales en la construcción de narrativas hegemónicas del alzamiento. El uso público de imágenes religiosas de raigambre popular y de diferentes festividades facilitó la articulación de consensos en torno a los significados de lo nacional y lo popular, permitió legitimar la represión en clave de cruzada y de regeneración nacional y contribuyó con la exaltación de la muerte en nombre de la religión y de la tradición. Nuestro objetivo, a partir del análisis comparativo de las prácticas populares en torno a las devociones y rituales de Badajoz y Cáceres, es aportar una lectura historiográfica-antropológica sobre la hegemonía del franquismo en dos ciudades que entraron en la guerra de forma diferenciada.

La provincia de Cáceres se sumó al alzamiento siguiendo las órdenes del General Jefe de la VII División, Andrés Saliquet, sublevándose el Regimiento Argel el día 19 de julio, junto con las plazas de Plasencia, Coria y Valencia de Alcántara. Apenas se produjeron enfrentamientos y hasta diciembre de 1936 no se produjo una represión política sistemática con los fusilamientos de Navidad (Veiga López 1993; Chaves Palacios 2008; Rina Simón 2012). Por su parte, la provincia de 
Badajoz se mantuvo leal a la República hasta que la columna del general Yagüe avanzó en los primeros días de agosto desde Sevilla, tomando su capital la tarde del viernes 14 de agosto de 1936 (Espinosa Maestre, 2003 y 2012). Entre el 18 de julio y el 14 de agosto, la capital de provincia y la resistencia estuvo comandada por el Coronel Puigdengolas, nombrado jefe de la plaza el día 25 por el gobernador civil Miguel Granados y por el alcalde Sinforiano Madroñero, en sus puestos desde las elecciones que venció el Frente Popular (Alonso García 2014; Pilo Ortiz, Domínguez Núñez y De la Iglesia Ruiz 2016). El coronel intentó organizar una resistencia a todas luces insuficiente, iniciándose inmediatamente tras la toma una represión masiva considerada una de las matanzas de mayor alcance y repercusión durante la guerra (Neves 2007).

En relación a la religiosidad popular, durante estas tres semanas apenas se produjeron ataques de especial significación iconoclasta. La Semana Santa, por ejemplo, llevaba sin festejarse con procesiones desde la proclamación de la República, más que por una expresa prohibición gubernamental, se debió a un desinterés que venía siendo patente desde la década de los años veinte, eclipsada la fiesta por la pujanza del Carnaval pacense. Sólo mantenían popularidad y arraigo dos imágenes con rituales y significaciones diferenciadas. Por un lado la Virgen de la Soledad, que si bien no salió en procesión durante la etapa democrática, sí que mantuvo su valor como icono protector y popular de la ciudad, contando con el favor del alcalde y de otras autoridades. Durante este período además su templo recibió importantes ayudas para su construcción. Hasta el 14 de agosto de 1936, la imagen y su templo fueron respetados, incluso por el centenar de milicianos venidos de Madrid para apoyar la resistencia, comandados por el diputado socialista Nicolás de Pablo, que sí tomaron otros edificios religiosos, como el palacio arzobispal -entregado a las Juventudes Socialistas Unificadas-, el convento de Santa Ana, el seminario San Atón y el convento de las Adoratrices, registrando éste último ataques iconoclastas con imágenes decapitadas y quemadas y un San José fusilado. Además, se produjeron algunos desperfectos en la Catedral y en la iglesia de Santo Domingo, donde fue tiroteada la imagen de la Virgen de la Medalla Milagrosa. Esta iglesia concentró buena parte de los ataques iconoclastas y posteriormente se convirtió en uno de los centros neurálgicos de las celebraciones franquistas. Su localización era privilegiada: junto al cuartel de la Guardia Civil que se había sublevado en agosto contra la República, cercana al consulado de Portugal y en una zona ocupada por la burguesía acomodada.

En la construcción y consolidación del franquismo, estos ataques fueron recordados de manera dicotómica y las imágenes exaltadas y sacadas en 
procesión en actos de purificación y reconversión de la ciudad. En mayo de 1937, la procesión de la Virgen de la Medalla Milagrosa revistió "especial esplendor en acto de desagravio por la profanación que fue objeto en los días rojos." La ciudad se había salvado "del terror de las hordas marxistas" gracias a la "Santísima Virgen" (Hoy, 22/05/1937). Ante la imagen atacada se imploraba "su intercesión en favor de nuestro Ejército que continua derramando su sangre generosa por la salvación de nuestra España" (Hoy, 29/05/1938). En la plaza de Santo Domingo se celebraron también procesiones y actos de desagravio con el Sagrado Corazón, que adquirió un rango especial en la escala de patronazgo del nuevo Estado, compartiendo protagonismo con Santiago, la Inmaculada, la Virgen del Pilar y las devociones locales. En la procesión de junio de 1938 del Corazón de Jesús, la crónica periodística destacó "la cantidad de público (...), que ha constituido una prueba más de los sentimientos católicos del pueblo de Badajoz (...) una vez libertada de la esclavitud marxista (Hoy, 28/06/1938). En las celebraciones de la victoria, en la Catedral de Badajoz se organizó un quinario entre el 12 y el 16 de abril de 1939 dedicando cada día de rezo a una advocación relacionada directamente con las significaciones del nacionalcatolicismo y del espíritu de Cruzada: San José -patrón de la Acción Católica-, el Sagrado Corazón, la Virgen de la Soledad y la Inmaculada Concepción. La otra imagen popular de la ciudad, la Virgen de Bótoa, tampoco sufrió daño alguno. Sus rituales se enraizaban en tradiciones agrarias y al tratarse de un santuario situado en el campo, a kilómetros de la ciudad, se celebraba con caballos y otras manifestaciones simbólicas de riqueza agroganadera.

En Cáceres, la significación del alcalde socialista Antonio Canales con la Virgen de la Montaña, de la que era hermano y a la que nombró simbólicamente patrona de la UGT, reflejaba el carácter poliédrico de unas celebraciones y sistemas de creencias que superaban con creces su adscripción eclesiástica para erigirse en sistemas de identificación locales y espacios simbólicos de combate político por la definición de lo nacional, lo tradicional y lo esencial (Rina Simón 2016 y 2020; López Villaverde 2008). De tal forma, en ambas ciudades, con especial importancia en Cáceres, la religiosidad popular había superado los debates de laicidad e incluso había permitido sancionar el carácter tradicional y la continuidad histórica de la República con las costumbres y creencias del pueblo. $\mathrm{El}$ efecto boomerang, una vez consolidado el alzamiento en las dos capitales, fue mayor, resignificando y resacralizando con profundidad ritos, representaciones, imaginarios y creencias religiosas en un corpus sincrético y con pretensiones de homogeneidad que ligaba el Ejército y el Caudillo con la tradición, la historia y las mentalidades locales. El Movimiento, sancionado por la Iglesia como cruzada, 
vendría a restaurar el curso natural del pueblo español del que ideas extranjerizantes -liberalismo, democracia o comunismo- le habían apartado (Núñez Seixas 2006).

\section{NO SOLO MIEDO}

No cabe duda de que el miedo, la represión, el terror de la guerra y la cultura de la victoria fueron nucleares en la construcción del Estado franquista. Sin esa violencia y terror indiscriminado no es posible comprender la naturaleza política del régimen y su implantación en la sociedad española. Sin embargo, la historiografía en las últimas décadas, motivada principalmente desde la óptica de la historia cultural, ha apuntado a otros mecanismos de construcción del consenso franquista que, lejos de oponerse, se complementa con la violencia y la represión. En este sentido, cabe señalar la importancia de la autarquía y la carestía en la fabricación de consenso (Del Arco Blanco 2009); de los mecanismos banales y cotidianos de significación diaria del franquismo a través de los medios de comunicación (Molinero 2005; Rueda Laffond y Coronado Ruiz 2010); del aparato conmemorativo profundamente fascistizado en este período, con determinada lectura de la historia que situaba al Caudillo en un movimiento de resurrección nacional (Box 2010; Saz 2003); de la bendición fundamental de la Iglesia, tanto en el plano institucional con sus encíclicas como en el terreno local (Raguer 2008); de la construcción de un nacionalismo excluyente apoyado tanto en un potente aparato simbólico como en prácticas cotidianas y banales (Hernández Burgos 2018); y de la demarcación de lo que era tradicional, popular, festivo y consustancial al pueblo (Cruz 2006; Hernàndez i Martí 1996 y 2002; Rina Simón 2015). La significación de conceptos relativos a la tradición y las narrativas historiográficas teleológicas consolidaron una sublevación que vendría a restaurar un Estado, un ideal imperial y una esencia nacional perdida (Alares 2017). Una de las características medulares del franquismo fue su nacionalismo radical y totalizante, mecanismo que funcionó como principio de socialización de la población.

Los planteamientos que han abordado la hegemonía del nuevo Estado desde el "no sólo miedo" (Del Arco, Fuertes, Hernández y Marco 2013; Richards y Ealham 2010) han permitido complejizar los sustratos ideológicos, los consensos y los poliédricos apoyos de una dictadura que se prolongó durante cuatro décadas y que nunca abandonó sus principios de legitimidad: el alzamiento y la victoria. También cabría destacar la construcción del carisma del Caudillo (Moradiellos 2016; Saz 2019). El dictador concentró en torno a su caudillaje a las plurales 
familias políticas que se alcanzaron contra la legalidad republicana: el catolicismo político, el monarquismo autoritario y el fascismo y el falangismo. La concentración de todos los poderes del Estado y el Decreto de Unificación que le permitió controlar las expectativas del Movimiento contribuyeron, sin ninguna duda, hegemonizar un modelo de Estado y de sociedad basado en principios militares: unidad, jerarquía y disciplina, religiosos y políticos. Este sistema abarcaba a todos los agentes del país en clave organicista y se extendió con mecanismos múltiples como fueron los medios de comunicación -controlados en un principio por los propagandistas de Falange-, los fenómenos conmemorativos a escala nacional y local, el control del calendario festivo, la construcción de la feminidad por asociaciones católicas y por la Sección Femenina, el uso de imagotipos -como las cruces de los caídos- y de narrativas historicistas de un nacionalismo exacerbado, el control social y los esfuerzos de recatolización de la Iglesia en el espacio público. Pero también, en el ámbito privado, en el sistema educativo y en la resignificación de rituales festivos, prácticas y creencias y en la definición de los contornos de lo popular y lo tradicional. Si a ello le sumamos una masiva y sistemática represión política durante la guerra y la posguerra y un uso aterrador de la violencia, podemos acercarnos con mayor precisión a la poliédrica construcción de la legitimidad política y cultural del régimen. También la historiografía reciente ha contribuido a desechar el tópico del franquismo como dictadura militar sin una ideología específica. Los debates sobre la fiscalización del régimen, la conformación de sus culturas políticas y el sustrato nacionalcatólico de sus ideas, permiten considerarlo en términos historiográficos como un modelo de Estado profundamente ideológico y de vocación totalitaria al menos hasta 1945.

El giro cultural en este campo de estudio y los diálogos transdisciplinares han puesto el foco en los ritos como escenarios de representación de los imaginarios sociales y de las narrativas historiográficas, aspectos que contribuyeron a consolidar los imaginarios franquistas. La afirmación de Miguel de Unamuno en el paraninfo de la Universidad de la Salamanca de "vencer no es convencer" no puede darse por válida. Las autoridades sublevadas se afanaron desde los primeros compases de la guerra en "convencer" con diferentes mecanismos psicopolíticos e identitarios que asimilaron la cultura franquista con la cultura nacional (Box 2017, 2007, 2004; Hernández Burgos 2016; Vincent 2009; Del Arco Blanco 2018). La fuerza de símbolos, ideas y conceptos no fue sólo retórica ni se movió apenas en el horizonte de las representaciones, sino que condensó proyectos y expectativas que confluyeron en una praxis política determinada. 


\section{RELIGIOSIDAD POPULAR, TRADICIÓN Y LEGITIMIDAD}

Las élites políticas, culturales y religiosas del nuevo Estado fagocitaron las prácticas y creencias relacionadas con la tradición, lo popular y lo telúrico. Para ello se valieron de la resignificación de rituales y símbolos del espacio público. La movilización de estos elementos facilitó la construcción de consensos con mecanismos que, si bien estaban revestidos de tradición, formaban parte del ámbito cultural de la modernidad (García Pilán 2006 y 2009: 14-40). Entre ellos destacó el culto a los mártires-caídos (Koselleclk 2012; Mosse 2016), con una doble funcionalidad: por un lado, dar un sentido a la muerte y estimular a las tropas a entregar su vida por el ideal nacionalista, religioso o fascista; $y$, por otro, articular un discurso que sustentara los orígenes del "Movimiento" en hazañas heroicas y en la entrega desinteresada de la sangre, memoria que se perpetuaría en el imaginario colectivo a través de fiestas y rituales conmemorativos y en la erección de cruces monumentales, que se convirtieron el epicentro de las manifestaciones de adhesión al régimen y de recuerdo de la guerra (Del Arco Blanco 2013). El fin de este despliegue sincrético de ritos y símbolos era escenificar en el espacio público y en el horizonte de las creencias y de las identidades locales las narrativas de la resurrección -palingeneisa- o restauración -apocatástasis- de España. A la nacionalización se sumó la recatolización y purificación de la comunidad y del espacio "mancillado" por la República, movimiento justificado por la supuesta iniciativa popular de restaurar sus rituales y creencias.

Uno de los debates abiertos sobre los límites de los estudios sobre la legitimidad y el consenso es la dificultad para calibrar el apoyo popular a determinado régimen político en un sistema dictatorial, en el que no hay libertades para manifestar nada que no sea adhesión y en el que las leyes castigan y reprimen cualquier tipo de disidencia. Además, las fuentes con las que trabajamos: prensa -los rotativos católicos Hoy de Badajoz y Extremadura. Diario Católico de Cáceres y el falangista Falange de Cáceres-, documentos emitidos por el Estado, libros de actas o fotografías muestran unos niveles masivos de adhesión -con tanta insistencia que se podría pensar en un uso performativo de la masa- que no resuelven las dudas en torno al comportamiento impostado o a la aceptación fingida de la legitimidad. Se trata de una problemática metodológica y epistemológica central para la historiografía del franquismo.

Las celebraciones vinculadas a la religiosidad popular, como manifestaciones de fuerte arraigo en la comunidad, desempeñan una relevante función en la articulación de símbolos, discursos e identidades sociales, susceptibles de 
presentar diferentes lecturas ideológicas. El nacionalcatolicismo se valió de este conjunto de rituales y creencias para legitimar la dictadura en principios supraterrenales. Como apuntara el publicista nacionalcatólico José Pemartín en 1937:

el pueblo cree lo que ve como previo paso para creer en lo que no ve; y si ve a las autoridades rindiendo culto Católico a Dios, si ve a las fuerzas armadas presentando armas al Santísimo Sacramento, si ve el esplendor del Culto Católico Español (...), cree efectivamente que aquello a lo que se rinde Culto exterior es a la verdad (Pemartín 1937: 85).

Un análisis superficial de la religiosidad popular podría llevarnos a confundir los rituales con celebraciones, usos y costumbres pretéritas. Sin embargo, los comportamientos de las cofradías y devotos fueron tamizados y adaptados a los nuevos condicionantes ideológicos en pugna por un mayor peso simbólico en la memoria pública de la dictadura. Las instituciones franquistas buscaron en estas celebraciones colectivas articular un discurso homogéneo y sacralizado de la figura del Caudillo y de la consustancialidad católica del pueblo español representada en las tropas sublevadas.

La importancia simbólica de esta religiosidad fue percibida desde el primer momento por los militares sublevados, que transformaron sus manifestaciones públicas en un medio de consolidación del nuevo Estado y de socialización bajo los nuevos principios del nacionalcatolicismo. El franquismo se valió de todo un entramado de imaginarios y memorias para presentarse como el baluarte de los ritos tradicionales y populares, consustanciales a la identidad inmemorial de la nación. Las nuevas instituciones y su conformación antirrepublicana e integrista católica alteraron el simbolismo y las funciones de la religiosidad popular para transformar las cofradías en agentes catequizadores de los principios políticos del régimen, modificando la representatividad y socialización de las mismas. A través de estos acontecimientos festivos, el régimen proyectó sus valores y su escala jerárquica, aprovechando las manifestaciones colectivas para evangelizar y homogeneizar el pensamiento gracias a la simbiosis entre procesiones, desfiles militares y aparato fascista. Esta simbiosis se concretó en un escenario de asimilación colectiva por el cual la Pasión, Muerte y Resurrección de Cristo se presentaron como metáforas de la propia muerte y resurrección de España. Las imágenes con mayor devoción y las que contaban con el fervor de un sustrato socioeconómico más humilde, fueron adornadas con insignias políticas y militares. Ante ellas desfilaban los ejércitos y se les rendía los mayores honores 
militares. De esta forma, los rituales populares se convirtieron en celebraciones del régimen, confundiéndose procesiones y rosarios vespertinos con entierros de falangistas y misas de campaña (Rina 2015).

\section{USOS DE LA RELIGIOSIDAD POPULAR EN CÁCERES Y BADAJOZ DURANTE LA GUERRA CIVIL}

Los usos y representaciones de la religiosidad popular durante la guerra contribuyeron a construir los relatos y los imaginarios de legitimidad del bando sublevado. En nombre de lo sagrado, pero también de lo popular y tradicional y de los iconos identitarios de la comunidad, se libró una batalla contra unas fuerzas republicanas, liberales o socialistas que habían "traicionado" al tronco telúrico de creencias y manifestaciones esenciales españolas. Las primeras medidas en ambas capitales de provincia de las autoridades sublevadas fue apropiarse de las significaciones y voluntades de las patronas, la Virgen de la Montaña en Cáceres y la Virgen de la Soledad en Badajoz, que actuaron desde entonces como legitimadoras del alzamiento, protectoras de la población y símbolos de la recatolización y purificación del espacio nacional. Ambas imágenes representaban lo puro y prístino. En una dialéctica maniquea, la memoria del periodo republicano fue profundamente mistificada, especialmente en el caso de la Virgen de la Montaña, para simbolizar la restauración de las creencias y la idiosincrasia popular del pueblo español.

Durante la guerra civil, en la zona nacional, se produjo, tal y como ha señalado el historiador Álvarez Bolado (1995), una excepcional movilización de vírgenes y otros iconos religiosos en apoyo a la cruzada. En Badajoz la Virgen de la Soledad permaneció meses en la Catedral y en cada conmemoración importante -14 de agosto, 18 de julio, visita de alguna autoridad relevante, desfile de la victoria, etc.- salió en procesión o en rogativa para simbolizar el pacto entre la dictadura, la religión y la tradición local. En la ermita de la Soledad todos los viernes durante el conflicto se celebraron adoraciones eucarísticas y rezos pidiendo la victoria y salvación de España. La Virgen fue movilizada en sucesivas ocasiones para acudir a la catedral y en octubre de 1937 fue nombrada patrona de FET y de las JONS (Hoy, 29/10/1937). Meses antes, en su procesión en la Semana Santa de 1937, se le cantó esta jota: "aún pretende el soviet / de nuestra España arrancarle / olvidando que te guardan / las milicias de Falange” (Hoy, 27/03/1937).

Por su parte, en Cáceres la vinculación con el patronazgo de la Montaña fue aún más intenso. La Virgen fue bajada y colocada en la iglesia de Santa María con una gran bandera nacional ocultando el altar mayor y fue sacada en procesiones para 
festejar diferentes victorias y efemérides del régimen en la plaza renombrada como General Mola. Los invitados del régimen que visitaron la ciudad durante la guerra -el caso más significativo fue el de Pilar Primo de Rivera- se postraron ante la imagen en señal de restauración y acatamiento a las creencias y a los ritos populares (Rina Simón 2012). La imagen rápidamente recibió un nombre de calle y su salida anual de abril se convirtió - coincidiendo con la festividad de San Jorge- en el ritual medular del nuevo Estado en la ciudad, con misas de campañas, Te Deum, desfiles militares y procesiones con una masiva asistencia de público que saludaba brazo en alto al modo fascista a la Virgen.

En la primavera de 1937, la Comisión Gestora de la ciudad de Cáceres retomó las celebraciones en torno a su patrona que no habían podido celebrarse el año anterior por imperativo del Gobierno Civil. La vinculación de las autoridades con el patronazgo de la Virgen otorgó un papel principal a las instituciones políticas en las procesiones y romerías. La procesión de aquel año fue recibida en las puertas de la ciudad -en Fuente Concejo- por el alcalde, que entregó su bastón de mando a la Virgen. El cortejo representaba el amparo providencial del alzamiento militar, escoltando la procesión cuatro alféreces del Regimiento Argel hasta la plaza del general Mola, donde el paso fue colocado en las puertas del Ayuntamiento para celebrar una misa de campaña presidida por el obispo Fray Barbado Viejo. Durante la guerra, la Virgen de la Montaña se convirtió en la protectora de los soldados, revestida de simbología militar, y en la intercesora entre la divinidad y la ciudad. La Comisión Gestora, en marzo de 1938, instauró el rezo del rosario semanal para corporaciones, entidades y particulares ante la Virgen", "para que durante el mismo la ciudad entera pueda rendir pleitesía a la madre de Dios" (Extremadura. Diario Católico, 24/03/1938). En agosto de 1937, FET y de las JONS ya había publicado una circular invitando a cadetes, flechas, pelayos y el resto de falangistas a que fueran "diariamente a rezar una Salve a la Patrona de Cáceres. No dejéis de hacerlo para ser dignos de Cáceres y de la camisa azul, que tiene el color del cielo y de la Virgen" (Falange, 30/08/1937).

Las menciones de las autoridades a la Virgen fueron constantes. El diario cacereño Falange publicaba en noviembre de 1936 la carta de agradecimiento de Manuel Álvarez, coronel jefe del Regimiento Argel responsable el alzamiento en la ciudad, expresando su agradecimiento a la Comisión Gestora por haberle nombrado hijo adoptivo de Cáceres. En la carta ponía de manifiesto su "reconocimiento (...) hacia la Santísima Virgen de la Montaña." Sus gestas tuvieron "la protección de nuestra Excelsa Patrona (...), la que ni un momento

${ }^{1}$ AHMC, Actas de la Comisión Gestora, 16/03/1938 
nos abandonó." Concluía, encomendándose a la Virgen de la Montaña, "Virgen Cacereña y española, con el mismo fervor que en aquellos días de atribulación para nuestra Madre España, que estés a nuestro lado, que nos guíes y nos ampares, porque sabes gloriosamente de las cosas de guerra que tienes la gratitud de todos los buenos españoles, de los hijos de la España Católica, a quienes los traidores no pudieron quitar su fe ni pudieron vencer; que seas tú, Virgen de la Montaña, Virgencita de los cacereños y española, la que traces la ruta de la nueva España: que seas tú (...) quien guie sus pasos en la historia" (Falange, 05/11/1936).

La Comisión Gestora el día 4 de diciembre de 1936 nombró la calle 1o de Mayo como Virgen de la Montaña, interpretando "con ello los sentimientos de todos los cacereños, que sin excepción, y aun en los tiempos de persecución de la religión, siempre defendieron con sus pechos y con el corazón bueno que en ellos se encerraba, a la Virgen de la Montaña." (Falange, 05/12/1936). La prensa local manifestaba el poder de convocatoria de la Patrona en cada acto conmemorativo de los avances militares de los sublevados:

De la devoción que el pueblo siente por su Patrona da idea exacta la insuficiencia del templo parroquial para albergar al incontable número de fieles que acuden todas las noches a postrarse ante la Virgen y orar por la salvación de España (...). El pueblo de Cáceres, de tradición enteramente religiosa y que en el recuerdo de todos los tiempos y vicisitudes por los que ha atravesado la Patria, supo mantener la fe viva de sus mayores y corresponder a las gracias y favores que derrama la Santísima Virgen de la Montaña sobre nuestra ciudad y sus hijos (...). La Patrona de Cáceres, huésped de la ciudad, recoge las súplicas de sus hijos y no ha de tardar en que esa protección se ponga de manifiesto el día en que acompañada de todo el pueblo regrese a su Santuario, coincidiendo con el triunfo final de la Cruzada y el aplastamiento del comunismo ateo (Extremadura. Diario Católico, 27/04/1938).

Igualmente, la Virgen ocupó un papel central en las celebraciones de la victoria visitando las cuatro parroquias en acción de gracias: "por su intención valiosísima vendrá la verdadera paz para España que se afana de ser la nación mariana por excelencia" (Falange, 24/04/1939).

Las diversas familias políticas del nuevo Estado pugnaron por significar la voluntad de estas imágenes y sus rituales, bien para vincular el alzamiento con la tradición de la comunidad, bien como herramienta de recatolización y de 
construcción de consenso sociales. Las procesiones en ambas ciudades fueron síntesis representativa de la nueva estructura jerárquica del franquismo. En ellas participaban flechas, margaritas, pelayos, todas las autoridades políticas y militares, las jerarquías falangistas y requetés, escuadras y bandas militares, estandartes de todas las congregaciones religiosas y la presidencia del Obispo, el alcalde y sus concejales, el gobernador civil, el presidente de la diputación, jefes de la Guardia Civil, de Carabineros y de la Guardia de Asalto, así como otras autoridades, funcionarios públicos y el consulado de Portugal.

El alcalde de Cáceres Luciano López Hidalgo -comandante vinculado a la sublevación- entre 1936 y 1937 -después pasaría a presidir la Diputación y en 1939 se convirtió en Gobernador Civil- fue significativamente insistente en la intercesión y apoyo de la Virgen de la Montaña al ejército nacional. Si analizamos sus discursos, comprobamos cómo la Patrona comparte espacio de relevancia con "España" o "Franco". López Hidalgo utilizaba también el icono mariano para justificar su gestión municipal y las políticas sociales.

Pero no sólo las patronas fueron movilizadas. En Badajoz cobraron especial significación aquellas imágenes que habían sido objeto de ataques iconoclastas entre el 18 de julio y el 14 de agosto de 1936. Es el caso de la Virgen de la Medalla Milagrosa anteriormente referido, que adquirió una simbología de restauración de la tradición y de lo popular. Otro ejemplo sería el de la Virgen de la Luz de la parroquia de Santa Marina, que había sido incendiada y, tras una pronta restauración, salió en procesión en febrero de 1937 en señal de purificación y reconquista simbólica del espacio (Hoy, 20/02/1937). Otro caso paradigmático fue el de la procesión de la Virgen de la Merced de San Andrés, que adquirió especial relevancia en los actos de celebración de la toma de Barcelona (Hoy, 01/02/1939).

A esta movilización mariana en actos de purificación del espacio contribuyó el diario $H o y$-en manos católicas excepto en 1938, cuando la dirección recayó en órganos de la Falange y el espacio dedicado a la religión y a la cruzada se redujeron sensiblemente-, con la publicación recurrente de imágenes religiosas destrozadas en aras de perpetuar la memoria de los ataques iconoclastas. "¿Veis esas imágenes mutiladas por las hordas rojas y separatistas? Pues constituyen el espectáculo habitual de los territorios recién conquistados por el ejército" (Hoy, 27/08/1937). En febrero de 1937, tras celebrar la prohibición del Carnaval por tratarse de una celebración "atea" y "anarcomarxista", el editorial de Hoy se unía a la carta pastoral del Cardenal Gomá celebrando la cruzada y la entrega de la Iglesia a "esta contribución universal de dolores con el número fabuloso de sus 
mártires y de sus muertos (...). Pero este dolor se intensifica, si le añadimos la de casi media España, sin templos y sin cruces. Con ateísmo e infernal descreimiento" (Hoy, 23/02/1937).

Si bien muchas imágenes se encontraban relativamente olvidadas y sin cultos externos antes de la República, las autoridades, el clero y la prensa afín al alzamiento pronto construyeron relatos del pasado en los que el esplendor de estas devociones y de sus rituales había sido interrumpido por el laicismo y la violencia republicana. El nuevo Estado había emprendido la guerra para la salvación de España y de su idiosincrasia particular, para lo que fue necesario un importante proceso de construcción y localización de esos caracteres en clave esencialista e historicista.

También podemos destacar los usos políticos de la Virgen de Guadalupe que, además de Patrona de Extremadura, permitía conectar la religiosidad popular con las expectativas imperiales y el recuerdo historicista de la conquista de América:

La devoción y el fervor que en todo pecho extremeño tuvo siempre la morenita de las Villuercas, siente este año de reconquista y gloria de la patria, el renovado entusiasmo de aquellos otros en los que era capitana de nuestro ejército, también vencedor y glorioso contra los infieles.

La Virgen, en sus diversas advocaciones, había obrado "el renovado milagro de nuestros triunfos. Ella detuvo las hordas a las puertas mismas del valle cuando venían como tromba maldita a asolar la religión. Ella ilumina el dulce morir de los que caen luchando por su fe y por España (...). La victoria es la misma victoria de la Virgen" (Hoy, 08/09/1937). En Badajoz, los actos en honor a la Patrona de Extremadura se concentraron en la iglesia de la Concepción -lugar de acogida para la restaurada orden jesuita-, donde se celebraron todos los sábados oraciones ante la Virgen para pedir por la victoria y por los mártires de la cruzada. El monasterio de las Villuercas se convirtió en centro neurálgico de las memorias de la hispanidad de la dictadura, sobre todo a raíz de la visita de Franco el 19 de marzo de 1940.

\section{EL RELATO PALINGENÉSICO DE LA SEMANA SANTA}

La semana Santa fue un escenario privilegiado para la construcción de la hegemonía y de las narrativas palingenésicas y de apocatástasis del franquismo. 
España, con su Caudillo, tras la Pasión -del liberalismo, el laicismo, la masonería o la democracia- había muerto -especialmente durante la República-, pero resucitaba con la sublevación. La sangre derramada era consagrada al resurgimiento nacional y en la iconografía de los pasos procesionales Cristo parecía caminar sobre España. "Después del sacrificio, de la pasión, del esfuerzo, de las privaciones, del dolor, viene la gloriosa hora del resurgir mayestático (...) a los valores eternos, a las bienaventuranzas. España ayer de pasión. Hoy de Gloria" (Hoy, 23/02/1937). Estos rituales se revistieron durante la guerra de una profusa simbología fascistizada -resultado de la comunión de objetivos entre las autoridades eclesiásticas y el falangismo, que se fracturó una vez acabada la guerra y celebrada la victoria-. Pero también sufrieron un proceso de militarización -con la presencia de mutilados que, como Cristo, entregaban su sangre por la salvación de España- y purificación por parte de unas autoridades eclesiásticas que vieron la oportunidad histórica para reconducir la religiosidad popular hacia los templos:

Nada de cesión al placer, ni siquiera el recreo lícito y al honesto esparcimiento. Juntamente con Cristo exprimen su corazón para derramar hasta la última gota de su sangre y de su amor innumerables hermanos nuestros, fieles al Gran Capitán que es Jesús, el del Calvario. Clavada en la Cruz está la madre España (Hoy, 27/03/1937).

Estos rituales fueron resignificados con simbología fascistizada y durante la guerra al paso de las procesiones el público y las autoridades políticas y religiosas cantaron los himnos nacionales y saludaron brazo en alto a las imágenes, práctica que se extenderá a todo tipo celebraciones, como la de los Reyes Magos, recibidos por el público pacense también al modo fascista (Hoy, 05/01/1938). Otro de los rasgos de la fascistización fue la redundancia mediática del discurso palingenésico, que intercambiaba Cristo por España en las oraciones. Sirva este ejemplo del soldado Enrique del Corral en la sección del Hoy de "Cartas del combatiente" con el título de “¡Resurrexit!":

Después de la Amargura, después de la Pasión, España (...) viene a nosotros en la plenitud de una nueva mañana histórica (...), resucita entre lucha, sangre y luto y alegría de vida. España resucita y se eleva (...). ¡Sube España! ¡Resurrexit! Venga a nos tu Imperio, España nueva, creadora, madre, amiga, hermana, novia, ¡España Imperial! (Hoy, 04/09/1937). 
En la Semana Santa de 1938 -cuyo Jueves Santo, el 14 de abril, coincidía con la efeméride de la proclamación de la II República-, el diario cacereño en manos del obispado Extremadura. Diario Católico dedicó buena parte de sus páginas a la justificación de la guerra como cruzada y a la asimilación entre la pasión, muerte y resurrección de Cristo con el Calvario de la patria y la redención por Franco. Así lo explicó Emilio Tierno Sánchez en su texto "Crucifixión de España":

Es el destino que, en lo humano, nos ha dado Dios. Las Grandes empresas de la Historia Universal han sido realizadas por españoles. Contra el turco y contra los protestantes, España supo mantener enhiesta la bandera de la religión católica. Por ello ha tenido que crucificarse, como lo está haciendo ahora (Extremadura. Diario Católico, 14/04/1938).

España, la patria católica, se estaba autoinmolando para salvar a sus hijos de los "sin Dios", “de la jauría extranjera." El Capellán Castrense del Regimiento Argel incidía en la Crucifixión voluntaria de la patria. Como la imagen del pelícano, sangrando para alimentar a sus crías, asimismo España había entregado su sangre redentora en los campos de batalla. Dolor y muerte redentora y purificadora. "Verdaderamente tú eres la hija de Dios en la Historia. Y este debe ser tu destino inmortal" (Extremadura. Diario Católico, 14/04/1938).

La esencia católica se manifestaba en la historia patria: Reconquista, Contrarreforma, Conquista y Evangelización de América, etc. La patria, a través de la guerra, se crucificaba, pero también sufría los Dolores de María, identificada con el dolor de las madres que entregaban a sus hijos en la santa cruzada. “¡Madre Dolorosa! -escribía el párroco de Santa María de Cáceres en el artículo "La Dolorosa"- Por el valor de nuestros héroes, por la sangre de nuestros mártires, por el sacrificio de nuestros soldados, compadécete del dolor de España" (Extremadura. Diario Católico, 14/04/1938). La Semana de Pasión de España se prolongaba por dos años en abril de 1938, pero la identidad católica de la nación, en palabras del párroco de Serradilla, llevaba "casi un siglo de dolorosísima pasión. (...) masones, judíos, liberales, separatistas y malos hijos, la han injuriado, escarnecido e insultado (...). Han hecho jirones su manto imperial (...), y si Dios no la hubiera hecho inmortal, habría desaparecido. (...) el Calvario de nuestra patria, alborea ya el Sábado de Gloria" (Extremadura. Diario Católico, 14/04/1938). El fuego de las armas y la sangre de los mártires purificarían el solar patrio y encaminarían a la nación hacia la redención. "¡Santa Pasión de Cristo! ¡Santa Expiación de España!” (Extremadura. Diario Católico, 
14/04/1938). Ese mismo día, en las páginas de este diario, el obispo de Coria, Fray Francisco Barbado Viejo, sancionaba la cruzada emprendida por la "España Católica" y la dimensión purificadora de la guerra en el texto "El dolor cristiano de España."

España se redime

por la sangre vertida en las batallas

venciendo a los herejes,

enemigos de Dios y de la Patria,

que vendieron a Cristo

por las treinta monedas de la infamia.

España se redime

con el milagro de su fe sin mácula

mientras huye la turba

que hizo guerra de furia iconoclasta.

Pero la madre amante

que espera de sus hijos la llegada

y busca las ovejas

que perdieron la senda de la raza, (...)

Prendido en el madero,

sufriendo la agonía más amarga

Jesús clamaba al Padre

perdón para la turba desmandada (...).

También España sufre

$y$ en angustias de guerra se desangra

para ofrecer a Cristo

el fruto redentor de la cruzada.

(JAVIMAR, "Rimas y Ripios", Extremadura. Diario Católico, 14/04/1938). 
El cronista de las procesiones de Semana Santa de Badajoz fue el archivero José López Prudencio, muy activo en la exaltación de la cruzada y en la construcción de la memoria franquista en la prensa -como Antonio Reyes Huertas, Antonio Silva, Antonio Floriano Cumbreño o José Ibarrola-_

Como hijos amantes de Badajoz vemos con su gran complacencia que, en este aspecto como en los demás, se conduzca nuestra ciudad en consonancia con la madre patria, procurando reencontrarse a sí misma, al resucitar sus santas y veneradas tradiciones.

Continuaba repasando en clave palingenésica la historia de la Semana Santa:

la ola de indiferencia y luego de hostilidad a los sentimientos religiosos tan reciamente españoles, que trajo la propaganda extranjera, había hecho casi desaparecer estas manifestaciones religiosas. Pero el vigoroso renacimiento español, que ha traído el glorioso Movimiento Nacional, ha hecho que la España auténtica se ponga en pie y renazca en el pecho de los españoles. No es raro que el fenómeno, en una población tan netamente española como Badajoz, tenga sus repercusiones castizas y se una a ellas el sentimiento religioso, restaurando sus veneradas tradiciones.

López Prudencio se mostraba nostálgico de un pasado prácticamente irrecuperable:

Pero la Semana Santa en aquellos años se revestía en Badajoz de un carácter que no ha vuelto a tener (...) Las galas de la indumentaria pomposa del Jueves Santo solían trocarse en el Viernes por trajes negros, y durante todos los días de la semana, desde el Martes Santo, era la devoción religiosa el tono principal de la vida de la ciudad." Pero fue decayendo "hasta que la República del 14 de abril las extinguió por completo (Hoy, 16/04/1938).

Los comerciantes de Badajoz intentaron revitalizar la Semana Santa pacense en 1938 organizando dos nuevas procesiones, la del Huerto el Martes Santo desde la iglesia de la Concepción y la de la Espina del Convento de las Descalzas el Miércoles Santo - esta última no salió hasta el año siguiente-:

Desaparecidos los obstáculos que impidieron la realización de estos actos, esta distinguida clase social se apresura a reanudar la honrosa tradición de su fe restaurando esta manifestación religiosa; y como 
hombres de la nueva España que al reencontrarse a sí misma, aparece vigorosa y católica, haciendo gala de su fe inquebrantable, se unen como los antiguos gremios, bajo las advocaciones de su devoción, para confesar a Cristo valerosa y notablemente (Hoy,12/04/1938).

Los rituales de la Semana Santa alcanzaron el cénit de significantes y simbolismo nacionalcatólico y fascistizado en la Semana Santa de 1939, que coincidió con la toma de Madrid y el parte final de guerra. López Prudenció firmó en Hoy:

“En España empieza a amanecer”, un texto de exaltación de la resurrección patria, cristiana y popular: "parecen sonar trompetas de resurrección que tañen ángeles devotos y lejanos. De Resurrección de España, que es Resurrección de fe y de fervor católico (...). Es España que se levanta de su postración con su fiel y su connatural fervor" (Hoy, 06/04/1939).

La crónica del diario católico de Badajoz celebraba el "gran número de muchachas lindamente ataviadas con la clásica mantilla española." Las autoridades "realizaron la piadosa visita, así como el vecindario en pleno que, en incesantes grupos, recorrían diversos monumentos de nuestras iglesias, que este año han rivalizado en buen gusto y riqueza de detalles ornamentales." Las mayores muestras de exaltación fueron para la Patrona:

Para dar una idea de la aglomeración incalculable de personas que acudían para mostrar su devoción a la Venerada Patrona, baste decir que la Virgen hubo de detenerse a las puertas de su templo durante media hora para poder abrir el espacio indispensable entre la compacta masa humana (...). Y sin que el esfuerzo denodado de los hermanos (...), ni la intervención infatigable de los agentes de la autoridad lograran organizar aquella imponente muchedumbre.

La procesión de la Virgen de la Soledad en la Semana Santa de la victoria "puso de manifiesto, de manera ostensible e impresionante, la veneración que siente hacia su Excelsa Patrona el Pueblo de Badajoz" (Hoy, 08/04/1939).

La prensa insistió en sus crónicas en la "participación masiva y total" del pueblo en las procesiones: "La manifestación puso de manifiesto no solo el fervor religioso de ese pueblo (...). Sin hipérbole puede decirse que el pueblo entero se apiñaba en las calles del tránsito para prestar el homenaje de su veneración y 
acatamiento a la Santísima Virgen" (Hoy, 13/10/1938). Fueron tan constantes estas referencias que podemos insinuar un carácter performativo. En toda la prensa extremeña de la época encontramos numerosos llamamientos a acudir a actos políticos, religiosos y militares y alguna breve nota criticando la escasa presencia de público Así, el 8 de abril de 1937 el diario Hoy hacía un llamamiento para acudir al Vía Crucis en la catedral por los Mártires Badajoz. “¿Lo has olvidado ya? ¿Quién compró tu libertad? ¿Quién regaló los bienes que disfrutas? ¿Quién abrió las puertas de tus cerrados y profanados templos?" Invitaba a acudir a la catedral "por los que cayeron a las puertas de nuestra ciudad, por todos los que se mueren en defensa de la Patria y para pedir a Jesús por su dolorosísima Pasión la terminación de la guerra, la salvación de España y el triunfo de la fe." Otro día, la invitación se convertía en reprimenda. El 13 de abril de 1939 en periódico Hoy se lamentaba de la escasa concurrencia al quinario de la victoria a la catedral, especialmente de hombres. Tres días después, el cronista del quinario señalaba que "si bien el templo ofrecía aspecto de gran solemnidad, no lo era de tanta como exige la terminación de la Cruzada Santa, el hecho de que con toda justeza ha sido calificado el más trascendental de los que han ocurrido en España desde la conquista de Granada por los Reyes Católicos" (Hoy, 16/04/1939).

Otro aspecto a destacar sería el interés institucional por controlar las pautas de conducta o la vestimenta femenina en el tiempo festivo. Durante la Semana Santa de 1937, el diario Hoy destacó en clave de alteridad con el período republicano la "vestimenta tradicional de las señoritas":

Tú, que como yo, lector amigo, recorriste ayer y anteayer las calles y plazas de nuestra capital extremeña, ¿te fijaste que diferencia con años anteriores? Las vistes rebosantes de gentes, de grupos de muchachas bonitas, alegres, hermosas, ataviadas con la clásica peineta y la casticísima mantilla, repleta de neto sabor español; comprobaste que los templos estaban abarrotados de fieles durante todo el día, asistiendo a todos los cultos celebrados, fuiste a las solemnes procesiones, en las que se hizo patente la religiosidad profunda de todo Badajoz; oíste las agudas saetas cantadas con la suprema unción de una sincera y arraigada fe. Todo ello, ¿no te hizo pensar, como a mí, la grotesca, sino encerrara un sentimiento criminal, afirmación de Azaña de que España había dejado de ser católica? (...) España, mientras España sea, será católica porque se lo impone una razón histórica indestructible (Hoy, 27/03/1937). 
El obispo de Badajoz, José María Alcaraz y Alenda, afecto a la sublevación desde el principio, fue entrevistado para el Hoy con motivo de la conmemoración del primer aniversario de la toma de la ciudad, actos a los que no pudo asistir por encontrarse en el funeral del cardenal Ilundain. Declaró que "nuestra cruzada ha sido una lucha por la Patria y nuestra religión" y que "el odio de los enemigos de Dios ha sido siempre contra personas de orden, contra nuestros templos, contra nuestra tradición y sentimientos más nobles.” A la pregunta de si estaba satisfecho con la religiosidad de la ciudad, respondió:
Inmediatamente que Badajoz pudo salir de la dominación marxista, volvió con más intensidad que nunca la vida religiosa a nuestro pueblo. Se volvía a los tiempos de nuestra gloriosa tradición española. Todos saben comprender ya y nuestro Movimiento así lo proclama: que las épocas más grandiosas de nuestra gran Historia tuvieron por base los sólidos fundamentos de nuestra religión. (...) Dios en los momentos más difíciles de nuestra patria, señalo a los hombres capaces de evitar su derrumbamiento y su destrucción. En esta etapa histórica que estamos viviendo, por decisión providencial, España encontró a su Caudillo que es además de gran guerrero y patriota ejemplar, un cristiano modelo de austeridad y grandeza de espíritu (Hoy, 16/18/1937).

En Cáceres, el entramado conmemorativo y memorialístico del franquismo se concentró en la Cruz de los Caídos, inaugurada el 10 de mayo de 1938 por Pilar Primo de Rivera en un ritual eminentemente fascistizado (Rina Simón 2015). Allí se celebraron misas de campaña, Te Deum, procesiones, desfiles militares, ofrendas florales, juras de bandera, recibimiento a autoridades, etc. Las conmemoraciones del nuevo Estado tomaron dos ejes: el altar de Santa María presidido por la Virgen de la Montaña y la Cruz de los Caídos. En 1938, "miles" de niños ataviados de blanco salieron en procesión de Santa María hasta la Cruz para festejar el día de la Ascensión de Cristo. La crónica hablaba de "una visión celeste, de las plegarias inocentes de los niños por nuestros caídos y por el triunfo de España" (Hoy, 27/05/1938). Pilar Primo de Rivera, los alféreces de Granada que juraron bandera en Cáceres el 16 de octubre de 1938 y el propio Caudillo repitieron este esquema ritual que conmemoraba el carácter popular y nacional de la sublevación y la entrega de la vida por la resurrección de la patria. 


\section{CONCLUSIONES}

A lo largo de estas páginas hemos desarrollado los usos y mistificaciones de la religiosidad popular en Cáceres y Badajoz durante la guerra civil como mecanismo de legitimación y de fabricación de consensos en torno a lo popular, lo tradicional, lo sagrado y lo telúrico de la comunidad. El uso público de imágenes con raigambre devocional fueron resignificadas en una serie de narrativas justificativas del alzamiento, la cruzada y del relato palingenésico del nuevo Estado. Estas imágenes sintetizaban el vínculo sagrado y popular entre lo local y lo nacional. Al mismo tiempo, la Semana Santa se convirtió en una celebración rigorista, en constante proceso de purificación, fascistización y militarización. El ritual escenificó el orden de representatividad del franquismo y dio cabida simbólica a las diferentes familias del régimen, convirtiéndose en un escenario privilegiado en el que vincular, durante la guerra civil, la sublevación con fenómenos populares y trascendentes. La teatralidad de las conmemoraciones de la pasión, muerte y resurrección de la patria en la Semana Santa de 1939 permitió consolidar el discurso palingenésico de la dictadura.

\section{BIBLIOGRAFÍA}

ALARES, G. (2017): Las políticas del pasado en la España franquista (1939-1964), Madrid, Marcial Pons.

ALONSO GARCÍA, H. (2014): El coronel Puigdengolas y la batalla de Badajoz, Valencia, PUV.

ÁlVAREZ BOLADO, A. (1995): Para ganar la Guerra, para ganar la paz. Iglesia y Guerra Civil, Madrid, Universidad Pontificia de Comillas.

BOX, Z. (2017): "Cuerpo y nación. Sobre la España vertical y la imagen del hombre", Ayer, 107, pp. 205-228.

- (2010): España, año cero. La construcción simbólica del franquismo, Madrid, Alianza.

- (2007): "La construcció de la memòria oficial. La legislació franquista sobre símbols", Afers, 56, pp. 41-59

- (2004): "Secularizando el apocalipsis. Manufactura mítica y discurso nacional franquista: la narración de la victoria”, Historia y Política, 12, pp. 133-160.

CHAVES PALACIOS, J (2008): Tragedia y represión en Navidad, Cáceres, Diputación de Cáceres. 
DEL ARCO BLANCO. M. A. (2018): "Before the Altar of the Fatherland: Catholicism, Politics of Modernization, and Nationalization during the Spanish Civil War", European History Quarterly, 48, pp. 232-255.

- (2013): "Las cruces de los caídos. Instrumento nacionalizador en la cultura de la victoria", en No sólo miedo. Actitudes políticas y opinión popular bajo la dictadura franquista (1936-1977), editado por Del Arco, M. A., Fuertes, C., Hernández, C. y Marco J., Granada, Comares, pp. 65-82.

- (2009): "El secreto del consenso en el régimen franquista: cultura de la victoria, represión y hambre”, Ayer, 76, pp. 245-268.

DEL ARCO, M. A., FUERTES, C., HERNÁNDEZ, C. y MARCO, J. eds. (2013): No solo miedo. Actitudes políticas y opinión popular bajo la dictadura franquista (1936-1977), Granada, Comares.

ESPINOSA MAESTRE, F. (2012): Guerra y represión en el sur de España: entre la historia y la memoria, Valencia, PUV.

- (2003): La columna de la muerte: el avance del ejército franquista de Sevilla a Madrid, Barcelona, Crítica.

GARCÍA PILÁN, P. (2009): Tradición en la modernidad avanzada: la Semana Santa Marinera de Valencia, Valencia, Diputació de València / Museu Valencià d'Etnologia.

- (2006): "Sociabilidad festera: retradicionalización selectiva y producción de sacralidades en la modernidad avanzada", Anduli. Revista Andaluza de Ciencias Sociales, 6, pp. 77-91.

HERNÁNDEZ BURGOS, C. (2018): "Franquismo suave. El nacionalismo banal de la dictadura”, en Ondear la nación. Nacionalismo banal en España, editado por A. Quiroga y F. Archilés, Granada, Comares, pp. 137-157.

- (2016): "De la cultura de guerra a la cultura de la victoria: los vencedores y la construcción de la dictadura franquista (1936-1951)", Pasado y memoria, 15, pp. 123-148.

HERNÀNDEZ I MARTÍ, G.-M. (2002): La festa reinventada. Calendari, politica $i$ ideologia en la València franquista, Valencia, PUV.

- (1996): Falles i franquisme a València, Valencia, Afers,

KOSELLECK, R. (2012): Modernidad, culto a la muerte y memoria nacional, Madrid, Centro de Estudios Políticos y Constitucionales. 
LÓPEZ VILLAVERDE, A. L. (2008): El gorro frigio y la mira frente a frente. Construcción y diversidad territorial del conflicto político-religioso en la España contemporánea, Barcelona, Rubeo.

MOLINERO, C. (2005): La captación de las masas: política social y propaganda en el régimen franquista, Madrid, Cátedra.

MORADIELLOS, E. dir. (2016): Las caras de Franco. Una revisión histórica del caudillo y su régimen, Madrid, Siglo XXI.

MOSSE, G. L. (2016): Soldados caídos. La transformación de la memoria de las guerras mundiales, Zaragoza, PUZ.

NEVES, M. (2007): La matanza de Badajoz, Mérida, Editora Regional de Extremadura.

NUÑEZ SEIXAS, X. M. (2006): ¡Fuera el invasor! Nacionalismos y movilización bélica en la Guerra Civil española, Madrid, Marcial Pons.

PEMARTÍN, J. (1937): ¿Qué es lo nuevo? Consideraciones sobre el momento español presente, Santander, Aldus Artes Gráficas, p. 85.

PILO ORTÍZ, F., DOMÍNGUEZ NÚÑEZ, M. y DE LA IGLESIA RUIZ, F. (2016): Balas de agosto. Badajoz 1936, Almería, Círculo Rojo.

RAGUER, H. (2008): La pólvora y el incienso: la Iglesia y la Guerra civil española, Barcelona, Península.

RICHARDS, M. y EALHAM, C. eds. (2010): España fragmentada. Historia cultural y guerra civil española, Granada, Comares.

RINA SIMÓN, C. (2020): “Combates políticos y culturales por la significación de la religiosidad popular durante la II República", Diacronie. Studi di Storia Contemporanea, 41, pp. 1-19.

- (2016): "Mistificaciones de la religiosidad popular durante la II República", Archivo Hispalense, 300-302, pp. 261-278.

- (2015): Los imaginarios franquistas y la religiosidad popular [1936-1949], Badajoz, Diputación de Badajoz.

- (2012): La construcción de la memoria franquista en Cáceres. Héroes, espacio y tiempo para un nuevo estado (1936-1941), Cáceres, UEX.

RUEDA LAFFOND, J. C. y CORONADO RUIZ, C. (2010): “La codificación televisiva del franquismo: de la historia del entretenimiento a la historia como entretenimiento", Historia Crítica, 40, pp. 170-195. 
SAZ. I. (2019): "Los poderes de Franco. Dictadura soberana y doctrina (s) del caudillaje", en La alargada sombra del franquismo. Naturaleza, mecanismos de pervivencia y huellas de la dictadura, editado por A. Esteban Recio, D. Etura y M. Tomasoni, Granada, Comares, pp. 111-132.

- (2003): España contra España. Los nacionalismos franquistas, Madrid, Marcial Pons.

VEIGA LÓPEZ, M. (1993): Fusilamientos en Navidad. Antonio Canales, Mérida, Editora Regional de Extremadura.

VINCENT, M. (2009): "Expiation as Performative Rhetoric in National-Catholicism: The Politics of Gesture in Post-Civil War Spain", Past and Present, 203-204, pp. $235-256$.

Recibido: 15 de diciembre de 2020

Aceptado: 25 de mayo de 2021

César Rina Simón es profesor en la Universidad de Extremadura (premio a la excelencia investigadora en 2021), doctor internacional en Historia por la Universidad de Navarra y miembro de grupo de investigación Use of the past de la Universidade de Lisboa. Se ha especializado en los mecanismos culturales de legitimación de la dictadura franquista desde una perspectiva transdisciplinar, prestando especial atención a las manifestaciones de la religiosidad popular. Entre sus obras sobre esta temática destacan: Los imaginarios franquistas y la religiosidad popular (Premio Arturo Barea, 2015) y El mito de la tierra de María Santísima. Religiosidad popular, espectáculo e identidad (2020). Ha editado la obra completa de Antonio Núñez de Herrera (2018) y junto a Zira Box el libro El franquismo en caleidoscopio. Perspectivas y estudios transdisciplinares sobre la dictadura (2020). cesrina@unex.es 